\title{
WETTELIJKE REGELING VAN HET PAR- TICULIERE BANKBEDRIJF IN FRANKRIJK
}

door Dr. H. W. J. Wijnholds

Bij de wetten van 13 en 14 Juni 1941 zijn in Frankrijk voorschriften gegeven betreffende het bedrijf van banken en daaraan verwante instellingen. De wet van 13 Juni 1941 (Loi du 13 juin 1941 relative à la réglémentation et a l'organisation de la profession bancaire) bevat de regeling van de banken, terwijl de wet van 14 Juni 1941 (Loi du 14 juin 1941 relative à la réglémentation et à l'organisation des professions se rattachant à la profession de banquier) bepalingen inhoudt omtrent instellingen en personen, die zonder het eigenlijke bankbedrijf uit te oefenen, financieele transacties verrichten, zooals het verleenen van credieten uit eigen middelen en het verhandelen van effecten.

De invoering van een wettelijke regeling van het bankwezen in Frankrijk is van bijzondere beteekenis, omdat Frankrijk tot voor enkele maanden één der weinige landen was, dat nog geen bankwet ${ }^{1}$ ) bezat. Thans zijn Engeland en Nederland 2) nog practisch de eenige landen zonder bankwet. In de meeste landen is het bankbedrijf reeds geruimen tijd aan een overheidscontrỏle onderworpen. De Fransche bankwetgeving moet dan ook niet worden gezien als een product van het streven naar ordening en overheidsbemoeiing van den laatsten tijd, hoewel uiteraard de inhoud wel het stempel draagt van den tijd, waarin $z$ ij werd geboren.

Niet allleen bestaat een wettelijke regeling van het bankbedrijf in andere landen reeds vele jaren, maar ook in Frankrijk is het denkbeeld van een dergelijke overheidscontrôle niet nieuw. Reeds in 1918 werd door de Commissie voor handel en industrie van het Huis van Afgevaardigden in een rapport de mogelijkheid daarvan onder het oog gezien. In 1922 deed Vincent Auriol, in naam der socialistische partij, in het parelment voorstellen in dien geest, terwijl de regeering in 1929 een commissie benoemde, met de opdracht om maatregelen ter bescherming van de spaarders voor te bereiden. Tot een algemeene regeling van het bankbedrijf 3 ) is het intusschen niet eerder dan in Juni van dit jaar gekomen ${ }^{4}$ ). Wel zijn in den tusschentijd een aantal incidenteele maatregelen met betrekking tot personen, die het bankbedrijf uitoefenen, en transacties, die de belangen van de spaarders dreigden te schaden, getroffen. Te vermelden valt hierbij nog de wet van 22 October 1940, waarbij werd bepaald, dat verschillende, met name genoemde, betalingen boven frs. 3000 door middel van overschrijving moeten geschieden.

1) Bankwet, hier dus niet op te vatten als wet betreffende de centrale bank, doch als wet ter regeling van het particuliere bankwezen.

2) Zooals men weet is het vraagstuk in Nederland bij een Staatscommissie in studie.

3) Teneinde misverstand te voorkomen zij hier opgemerkt, dat, wanneer in dit artike] gesproken wordt over wettelijke regeling van het bankbedrijf, onder ,bankbedrijf”, evenals zulks in de litteratuur over het onderwerp in kwestie geschiedt, in het algemeen wordt verstaan het bedrijf der depositobanken of algemeene banken. De bankwetten, die in de verschillende landen van kracht zijn, beperken zich veelal tot de genoemde soort van banken. Wettelijke voorschriften voor andere soorten van credietinstellingen $z$ ijn, indien dergelijke voorschriften bestaan, meestal in een afzonderlijke wet neergelegd. In het bijzonder is zulks het geval met de spaarbanken. Zoo bestaat in Frankrijk een uitgebreide en strenge regeling voor de spaarbanken, welke voorschriften reeds tot de eerste helft der vorige eeuw teruggaan.

4) Hierbij wordt afgezien van de door de bezettingsautoriteiten bij verordening van 22 Juli 1940 ingevoerde bankcontrôle. 
De wet van 13 Juni 1941, de eigenlijke bankwet, roept een drietal organen in het leven: de association professionnelle des banques, het comité permanent d organisation professionnelle des banques, entreprises et établissements financiers en de commission de contróle des banques.

De association professionnelle, die wij vereeniging van banken zullen noemen, is een organisatie, die alle banken in den zin der bankwet omvat. De banken moeten bij deze vereeniging zijn aangesloten, terwijl iedere andere organisatie van banken verboden is. Deze bepaling, die alle in dezelfde bedrijfstak werkzame instellingen in één beroepsorganisatie beoogt onder te brengen, valt als een uiting van het streven naar organischen opbouw van het bedrijfsleven te memoreeren. De vereeniging van banken staat onder toezicht van het comité d'organisation (zooals de officieele afkorting van den naam der tweede hierboven genoemde instantie luidt), die haar statuten moet goedkeuren. $Z_{i j}$ is belast met de bestudeering van vraagstukken, die met de uitoefening van het bankberoep samenhangen (in hoofdzaak technische kwesties) en onderhoudt voorts het contact tusschen haar leden en de beide andere genoemde organen.

Het comité d'organisation, in het vervolg aangeduid met organisatiecommissie, is belast met de algeheele leiding van de beroepen, die het geld - en credietwezen raken. Haar bevoegdheid strekt zich dus niet alleen uit over het bankbedrijf, doch ook over de beroepen, die geregeld zijn in de wet van 14 Juni 1941, zooals die van commissionnairs in effecten, wisselmakelaars, valuta-agenten en remisiers. De organisatiecommissie kan voorschriften geven met betrekking tot rente en andere tarieven, concurrentie, liquiditeit, personeelsopleiding, alsmede t.a.v. incidenteele gevallen, zooals fusies en sluiting van banken. Voorts doet zij voorstellen tot wijziging of aanvulling der bankwet. Hieruit blijkt wel hoe belangrijk de taak van deze commissie is. Ongetwijfeld is het zwaartepunt van de geheele bankwetgeving bij haar gelegen. Hoe de bankcontrôle zich in Frankrijk dan ook zal ontwikkelen hangt geheel van de organisatiecommissie af, althans totdat eventueel meer positieve voorschriften zullen worden vastgesteld. De organisatiecommissie bestaat uit maximaal zes personen, die door den Minister van Economische Zaken en Finansiën benoemd worden uit personen, die een leidende functie bij een bankinstelling vervullen. De Minister van Economische Zaken en Financiën laat zich door een regeeringscommissaris vertegenwoordigen.

De commission de controle of controlecommissie is belast met de zorg voor de naleving van de in de wet, uitvoeringsbesluiten en voorschriften van de organisatiecommissie genomen maatregelen. Met name behoort tot haar taak het controleeren van de door de banken ingezonden balansen en gegevens; zij kan een onderzoek ter plaatse doen instellen door inspecteurs van de Banque de France. De Minister van Economische Zaken en Financiën kan de door haar uitgeoefende contrôle ook uitbreiden over andere instellingen dan banken, zooals effectenfirma's. De contrōlecommissie bestaat uit den gouverneur van de Banque de France, als voorzitter, den directeur van de schatkist en den president van de organisatiecommissie.

Zooals uit het boventsaande blijkt, is bij de reglementeering van het Fransche bankwezen zeer veel ter regeling overgelaten aan de ingestelde 
organen, met name aan de organisatiecommissie. De bankwet geeft slechts hoofdlijnen; zij is in sterke mate een ",Rahmengesetz". Behalve de bepalingen omtrent de reeds besproken organen, bevat de wet de volgende voorschriften.

Onder banken worden verstaan ondernemingen of instellingen, die er haar beroep van maken gelden van het publiek aan te nemen en die voor eigen rekening te gebruiken voor disconteeringen, credietverleeningen of andere financieele transacties. Deze definitie komt vrij nauwkeurig overeen met die in de bankwetten van andere landen. Onder het „,aannemen van gelden van het publiek" wordt in dit verband niet verstaan het ontvangen van gelden, die slechts na twee jaar of langer kunnen worden opgevraagd. Hypotheekbanken en soortgelijke instellingen zijn dus geen banken in den zin der bankwet. Aan andere instellingen dan banken is het verboden om direct of binnen twee jaar opeischbare gelden van het publiek aan te nemen. Alle banken, volgens de genoemde definitie, ook de buitenlandsche, die in Frankrijk haar bedrijf uitoefenen, zijn aan de bankwet onderworpen. Dit impliceert intusschen niet, dat de bankwet in sommige gevallen ook niet op andere instellingen, die financieele transacties verrichten, van toepassing is. Hierboven bleek reeds, dat de organisatiecommissie ook zeggenschap over dergelijke instellingen heeft; $z \mathrm{ij}$ kan deze in bepaalde opzichten met banken gelijkstellen. ${ }^{5}$ )

Ondernemingen, die het bankbedrijf uitoefenen, kunnen slechts worden opgericht in den vorm van vennootschap onder firma, commanditaire vennoootschap of naamlooze vennootschap. Banken in den vorm van een coöperatie zijn dus uitgesloten. Deze bepaling trekt de aandacht, omdat in ons land de credietcoöperatie - speciaal in den landbouw - zulk een belangrijke plaats inneemt. In het buitenland is de groei van deze soort van credietinstelling echter niet zoo groot geweest en hebben de coöperaties in verschillende gevallen reden tot ontevredenheid gegeven (o.a. in België); in eenige bankwetten is de credietcoöperatie dan ook reeds verboden (b.v. in België en Zwitserland).

De banken moeten over een minimum-kapitaal beschikken, waarvan het bedrag door den Minister van Economische Zaken en Financiën wordt vastgesteld. ${ }^{\mathrm{a}}$ ) Voorts moeten alle banken worden ingeschreven in een register, dat door de organisatiecommissie wordt gehouden en in de Staatscourant wordt gepubliceerd.

Buitenlandsche banken worden in een afzonderlijk register ingeschreven. De organisatiecommissie gaat pas tot inschrijving over, wanneer de bank aan de gestelde vereischten heeft voldaan en wanneer de aanurage gerechtvaardigd is op grond van de algemeen economische en plaatselijke behoeften. In de gecursiveerde zinsnede komt duidelijk tot uiting, dat men in Frankrijk tot een ordening van den omvang van het credietapparaat wenscht te komen. Overigens moet worden opgemerkt, dat ook in andere bankwetten reeds dergelijke bepalingen bestaan. Het zal echter in de

5) De regeling aangaande de beroepsuitoefening van personen, die financieele transacties verrichten zonder dat daarbij sprake is van een bank in den zin der wet, zal in een volgend artikel worden besproken.

5a) $\mathrm{Na}$ het zetten van dit artikel werd bekend, dat het minimum-kapitaal voor banken in den vorm eener N.V. is vastgesteld op frs. 5 millioen en voor andere banken op frs. 1 millioen. Deze minima worden verdubbeld wanneer de banken meer dan twee bijkantoren hebben. De banken krijgen drie jaar den tijd haar kapitaal aan de nieuwe bepalingen aan te passen. Voor den overgangstijd heeft de contrôle-commissie voor de niet in Parijs werkende banken een minimum-kapitaal voorgeschreven van frs, 100.000 a frs. 1.000 .000 . 
practijk niet eenvoudig zijn te beoordeelen of een bepaalde instelling in een behoefte kan voorzien of niet. Instellingen, die niet in het bankregister zijn ingeschreven mogen het bankbedrijf niet uitoefenen, noch van de benaming bank, bankier of credietinstelling bij haar werkzaamheden gebruik maken.

Alle banken moeten haar boekjaar gelijk doen verloopen met het kalenderjaar. Op 31 December moeten de balansen en winst- en verliesrekeningen volgens een door de contrōlecommissie vastgesteld model worden opgesteld. De balansen moeten voor accoord met de boeken worden geteekend door een commissaris, die gekozen is uit een lijst, opgemaakt door het Hof van Appel. Deze commissarissen komen dus overeen met de bankreviseuren in België. Banken, waarvan de deposito's meer dan frs. 5 milliard bedragen, moeten voorts eenmaal per maand, de overige banken eenmaal per kwartaal, een balans opstellen en aan de contrōlecommissie inzenden. Banken met den rechtsvorm eener N.V. moeten de jaarlijksche en maandelijksche balansen alsmede de winst- en verliesrekeningen publiceeren in het bijvoegsel van de Staatscourant. De overige banken moeten halfjaarlijksche balansen publiceeren of ter beschikking van belanghebbenden stellen. Desgewenscht moeten aan de contrölecommissie toelichtingen of nadere gegevens worden verstrekt.

Ten slotte zijn voor overtredingen der bankwet de noodige sancties vastgesteld. Behalve de gewone rechter kunnen de straffen en andere maatregelen worden opgelegd door de organisatiecommissie en de contrōlecommissie. De bevoegdheden van deze beide commissies op dit stuk zijn zeer verstrekkend.

\section{Beoordeeling der bankwet.}

In het bovenstaande is reeds opgemerkt. dat de Fransche bankwet een "Rahmengesetzt" is. De beteekenis der wet hangt in hoofdzaak af van de mate waarin en de wijze waarop de organisatiecommissie van haar bevoegdheden gebruik zal maken. Vastgelegd in de wet is slechts de verplichting tot publicatie van balansen en de contrôle daarop. Het doel van de wet is dan ook in de eerste plaats de bescherming van de spaarders, waaronder in dit verband ook de deposanten zijn te verstaan. Minister Bouthillier heeft als grondslagen van de wet genoemd: organisatie van den beroepsstand der bankiers, bescherming van de spaarders en contrôle op de credietverdeeling. Daarbij heeft de minister opgemerkt, dat de maatregelen ter bereiking van het laatstgenoemde doel weinig ingrijpend zijn en dat de regeering in dit opzicht meer wilde "overtuigen" dan dwingen. De credietcontrôle in Frankrijk zal dus voorloopig wel beperkt blijven tot een kwalitatieve. In vergelijking met andere bankwetten is de regeling in Frankrijk weinig ingrijpend te noemen. ${ }^{6}$ ) In de meeste landen is het aanhouden van minimum-kaspercentages voorgeschreven. In sommige landen, speciaal de Vereenigde Staten, zijn deze percentages niet vast, doch kunnen zij hooger of lager worden vastgesteld teneinde den omvang van de credietverleening en daarmede de conjunctuur te beinvloeden. Deze kwantitatieve credietcontrôle kan behalve door het vaststellen van wisselende kaspercentages ook worden nagestreefd door ver-

6) Zie voor den inhoud van de bankwetten van andere landen het proefschrift van schrijver dezes, Wettelijke regeling van het particuliere bankbedrijf, Overzicht van de wetgeving betreffende de particuliere banken in verschillende landen. Utrecht 1938. 
hooging of verlaging der rente. Van de kwantitatieve credietcontrôle wordt hier melding gemaakt, omdat de Fransche bankwet aan de organisatiecommissie de middelen verschaft een dergelijke politiek te voeren en dus met de mogelijkheid daarvan in de toekomst rekening moet worden gehouden.

De structuur van het Fransche bankwezen is door de wet niet aangetast. Met name is de gemengde (aigemeene) bank gehandhaafd en is niet, zooals in België en de Vereenigde Staten een strenge scheiding gemaakt tusschen depositobanken en financieringsinstellingen. Men schijnt in Frankrijk een dergelijke scheiding intusschen wel overwogen te hebben, doch ervan te hebben afgezien op grond van de minder gunstige ervaringen, die daarmede in België zijn opgedaan.

In Fransche bankkringen is, blijkens uitlatingen in de pers, de bankcontrôle met gemengde gevoelens ontvangen. Men is van oordeel, dat het Fransche bankwezen heeft bewezen in het algemeen gezond en solide te zijn. Dit laatste kan niet worden ontkend, doch men verliest daarbij uit het oog, dat de invoering van bankwetgeving niet in de eerste plaats moet worden gezien als een reactie op bestaande of vermeende misstanden. $B_{i j}$ de invoering van de bankwetten in andere landen is daarop uitvoerig gewezen. Het zou ons echter te ver voeren daarop nader in te gaan.

Tot slot moge nog de aandacht worden gevestigd op het feit, dat de Banque de France niet als zoodanig in de organisatiecommissie (en wel in de daaraan feitelijk ondergeschikte contrōlecommissie) is vertegenwoordigd. Weliswaar is het mogelijk, dat de Minister van Economische Zaken en Financiën den gouverneur of een der directeuren van de Banque de France tot lid der commissie benoent, doch een verplichting in deze bestaat niet. Gezien het feit, dat de organisatiecommissie practisch over onbeperkte bevoegdheden ten aanzien van het bank- en credietwezen beschikt, moet het als een leemte worden beschouwd, dat de Banque de France daarin geen zeggenschap heeft. Daarentegen is de invloed van de regeering in de organisatiecommissie zeer groot, gezien het feit, dat de leden van de organisatiecommissie door den Minister van Economische Zaken en Financiën worden benoemd en ontslagen en dat een regeeringscommissaris in deze commissie het vetorecht heeft.

\section{BESLECHTE GESCHILLEN}

Red.: Prof. Mr Chr. Zevenbergen

(Bijdragen en mededeelingen zende men aan de Secretaris der Redactie)

Eigendomsoverdracht tot zekerheid. Rechtspositie van den zekerheidsontvanger in geval de zekerheidsgever failliet gaat of hem surséance van betaling wordt verleend.

Het heeft in ons land, anders dan in Duitschland 1) geruimen tijd geduurd, alvorens de eigendomsoverdracht tot zekerheid - ook wel fidu-

1) Verg. A. Koch, Kredit im Recht, 1925, bl. 44 v.; H. Wcinhausen, Die Sicherungs. übereignung, 3de dr. 1928, bl. $87 \mathrm{v}$. 